МЕТОДИЧНИЙ ПІДХІД ДО ЗАБЕЗПЕЧЕННЯ ДІєВОЇ ІННОВАЦІЙНОЇ ДІЯЛЬНОСТІ В ОРГАНАХ ВЛАДИ ДЛЯ РЕАЛІЗАЦІЇ ЕФЕКТИВНОЇ ДЕРЖАВНОЇ ЕКОНОМІЧНОЇ ПОЛІТИКИ

\author{
METHODICAL APPROACH TO ENSURING EFFECTIVE INNOVATION \\ IN AUTHORITIES TO IMPLEMENT EFFECTIVE STATE ECONOMIC POLICY
}

УДК 352.075.1(477).001.76

DOI: https://doi.org/10.32843/infrastruct54-11

\section{Шумська Г.М.}

к.е.н., доцент, доцент кафедри

державного управління,

публічного адміністрування

та регіональної економіки

Харківський національний економічний

університет імені Семена Кузнеця

Shumskaya Anna

Simon Kuznets Kharkiv National

University of Economics

\begin{abstract}
Обгрунтовано значення підвищення дієвості здійснення інноваційної діяльності в органах влади для реалізації ефрективної економічної політики держави. Запропоновано методичний підхід до забезпечення дієвої інноваційної діяльності в органах влади, який акцентує увагу на вдосконаленні нормативно-правового, інституиійного, кадрового, мотивачійного, науково-методичного, інформаційно-комунікаційного та фрінансового забезпечення інноваційної діяльності в органах влади. Використання запропонованого методичного підходу дасть змогу підвищити есрективність реалізації економічної політики держави та досягти високого суспільного розвитку в країні. Визначено зв'язок між процесом забезпечення дієвої інноваційної діяльності в органах влади та процесом реалізації ефективної державної й регіональної економічної політики, що грунтується на здійсненні результативного публічного управління та адміністрування.

Ключові слова: дієва інноваційна діяльність, органи публічної влади, державна економічна політика, публічне управління та адміністрування, професійні компетентності публічних службовців, інноваційна культура.
\end{abstract}

Обосновано значение повышения действенности осуществления инновационной деятельности в органах власти для реализа- ции эсрсрективной экономической политики государства. Предложен методический подход к обеспечению действенной инновационной деятельности в органах власти, который акцентирует внимание на усовершенствовании нормативно-правового, институционального, кадрового, мотивачионного, научно-методического, инфоормационно-коммуникационного и фринансового обеспечения инновационной деятельности в органах власти. Использование предложенного методического подхода позволит повысить эсрфрективность реализации экономической политики государства и достичь высокого общественного развития в стране. Определена связь между прочессом обеспечения действенной инновационной деятельности в органах власти и процессом реализации эфрфрективной государственной и региональной экономической политики, которая основана на осуществлении результативного публичного управления и администрирования.

Ключевые слова: действенная инновационная деятельность, органы публичной власти, государственная экономическая политика, публичное управление и администрирование, просрессиональные компетентности публичных служащих, инновационная культура.

In the article proves that improving the effectiveness of public administration is interrelated with the development of their innovation. The importance of increasing the effectiveness of innovative activities in authorities for the implementation of effective economic policy of the state and achieving high socioeconomic development in Ukraine is revealed. An analysis of comparative statistics on the ranking of Ukraine in the innovation sphere among other countries in recent years. The analysis revealed that Ukraine has the potential for innovative development, but so far there are significant obstacles to effective innovation policy in Ukraine: instability of the political and operational spheres; imperfect regulatory framework in the field of stimulating and supporting innovation; inefficient institutional support for innovation in authorities; insufficiently effective personnel policy to reduce staff resistance to innovation in authorities; insufficient level of motivation of public servants to acquire and apply new competencies in the field of innovation. In order to reduce these obstacles in the study, the methodological approach to ensuring effective innovation in authorities has been improved. This methodological approach, in contrast to the existing one, focuses on improving the regulatory, institutional, personnel, motivational, scientific and methodological, information and communication and financial support of innovation in authorities. A special place in this methodological approach is given to the process of implementing innovative personnel policy, which is based on: management of professional competence of civil servants (use of the scale for assessing the level of competence of civil servants and adjusting this level), assessment of readiness of public servants to innovate (selection of certain evaluation criteria) and on managing resistance to innovation in authorities. The author identifies the connection between the process of ensuring effective innovation in authorities and the process of implementing effective state and regional economic policy, which is based on the implementation of effective public management and administration.

Key words: effective innovation activity, public authorities, state economic policy, public management and administration, professional competence of public servants, innovative culture.

Постановка проблеми. Важливою умовою здійснення ефрективної державної економічної політики в непростому безперервно мінливому середовищі, в умовах ресорм $€$ результативне фрункціонування органів публічної влади в країні. Своєю чергою, дієва система публічного управління в Україні $€$ ключовим чинником прискорення темпів розвитку національної економіки, виходу 3 кризових ситуацій, розв'язання суспільних проблем в умовах обмежених ресурсів. Для того щоб органи публічної влади змогли на високому рівні виконувати свої функції, вони мають зазнати принципово якісних змін, в основі яких мають лежати нові підходи до забезпечення інноваційного розвитку системи публічного управління. Отже, без упровадження відповідних інновацій у систему публічного управління, які $є$ особливо необхідними в умовах рефрорм, органи влади не зможуть забезпечити ні надання якісних публічних послуг населенню країни, ні реалізацію ефективної державної економічної політики. Зазначене підтверджує актуальність та своєчасність даного дослідження.

Аналіз останніх досліджень і публікацій. Окремі теоретико-методологічні і практичні 
аспекти здійснення інноваційної діяльності в органах влади досліджувалися вітчизняними і зарубіжними вченими: І. Дегтярьовою, Ю. Карповою, А. Никифроровим, М. Петришиною, А. Пригожиним, Е. Роджерсом, С. Серьогіним, Ю. Шаровим [1-7] та ін. Проблематиці здійснення державного регулювання економіки та економічної політики присвячено праці багатьох науковців: Г. Башнянина, В. Бодрова, В. Геєця, В. Піхоцького, Д. Стеченка та ін. Проте виникає необхідність використання комплексного методичного підходу до забезпечення дієвої інноваційної діяльності в органах влади як основи реалізації ефективної державної економічної політики в умовах реформ. Окрім того, не в повному обсязі висвітлено зв'язок між процесом забезпечення дієвої інноваційної діяльності органів влади і процесом реалізації ефективної економічної політики держави. Усе вищезазначене обґрунтовує мету наукового дослідження.

Постановка завдання. Метою дослідження $€$ обґрунтування методичного підходу до забезпечення дієвої інноваційної діяльності в органах влади в Україні, що дасть змогу підвищити ефективність реалізації економічної політики держави в умовах рефрорм.

Виклад основного матеріалу дослідження. В умовах ресрорм, які запроваджуються в Україні, на передній план висуваються завдання підвищення дієвості публічного управління, яке може бути досягнуто на основі розроблення й упровадження органами влади інноваційних інструментів та технологій. Слід зауважити, що використання того чи іншого інноваційного інструменту, управлінської технології, підходу до управління, форми, методу роботи органів влади на практиці повинне базуватися не тільки на врахуванні накопиченого світового досвіду і наявних фрінансових ресурсів, а й на врахуванні особливостей їхньої роботи, що забезпечить дієвість і результативність здійснення інноваційної діяльності органами влади. При цьому дієвість інноваційної діяльності органів влади полягає у створенні сприятливих умов, по-перше, для реалізації ефективної державної і регіональної економічної політики та, як наслідок, досягнення стійкого розвитку національної економіки; по-друге, для прискорення темпів суспільного розвитку відповідно до стратегічних цілей завдань держави за мінімальних витрат на здійснення цієї діяльності шляхом удосконалення роботи органів влади (наприклад, використання того чи іншого інноваційного інструменту, технології, підходу до управління, фрорми, методу роботи органів влади).

Критичний аналіз провідних публікацій вітчизняних і зарубіжних учених щодо здійснення інноваційної діяльності органами публічної влади [1-9] дав змогу виділити такі інноваційні інструменти, фрорми і методи їх роботи, нові управлінські технології, підходи до управління, як: аутсорсинг - передача органом влади визначених функцій іншій організації, що спеціалізується у відповідній сорері; лізинг персоналу - залучення тимчасово вільного компетентного персоналу до діяльності органу влади за допомогою кадрових агентств, які займаються наданням таких послуг; бенчмаркінг; електронне урядування; збалансована система показників; концепція ощадливого управління; нове державне управління; підприємницький уряд; реінжиніринг; управління за цілями та результатами; методологія управління проєктами (розроблення і реалізація проєктів, грантрайтінг); публічно-приватне партнерство та ін.

Відповідно до оприлюдненого щорічного звіту «Глобальний інноваційний індекс 2020», в якому порівнювалася інноваційна діяльність 131 країни та економіки світу, найбільш інноваційними країнами у 2020 р. визнано Швейцарію, Швецію, США, Велику Британію, Нідерланди, Данію, Фінляндію, Сінгапур, Німеччину та Республіку Корея (десятка лідерів). У 2020 р. Україна посідала 45-е місце (підвищення на дві позиції порівняно із 2019 р.), а в групі за рівнем доходів «нижче середнього»- дурге місце після В'єтнаму та Індії. При цьому особливої уваги заслуговують позиції України за різними параметрами у рамках Глобального інноваційного індексу (місце, що посіла Україна): політична й операційна стабільність - 123; ефективність уряду - 93; інфрормаційні й комунікаційні технології - 89; урядові онлайн-послуги - 93; створення знань (патенти, винаходи) - 23 [10]. Відповідно до індексу інноваційного розвитку, представленого агентством Bloomberg у 2020 р. [11], Україна посіла 56-е місце (зниження на три позиції порівняно 32019 р.) серед 60 досліджуваних країн світу.

У Стратегії розвитку сорери інноваційної діяльності на період до 2030 р. [12] визначено основні бар'єри для розвитку інновацій в Україні, серед яких: недосконалість інституцій, зокрема політичного, регуляторного та бізнес-середовища; слабко розвинута інфраструктура, у т. ч. інноваційна, оскільки залишаються на низькому рівні показники валового нагромадження капіталу у відсотках до валового внутрішнього продукту, показники екологічної стійкості, доступності та якісної роботи електронного уряду. Як свідчать статистичні дані [13], в Україні значення показника валового нагромадження капіталу у відсотках до валового внутрішнього продукту за період із 2016 по 2019 р. скоротилося на 6,83\%: 3 21,72\% у 2016 р. до 14,89\% у 2019 р. Водночас, за даними Звіту щодо розвитку електронного урядування у 2020 р., Україна посідала 69-е місце у світовому рейтингу, тобто відносилася до країн із найвищим індексом електронної участі (у 2018 р. Україна посідала 82-е місце) [14].

Виходячи 3 вищенаведеного, Україна, безумовно, має потенціал до інноваційного розвитку, 
однак поки що є значні перешкоди для того, щоб наша країна посідала перші місця у міжнародних індексах у сорері інновацій. Серед основних перешкод проведенню ефективної інноваційної політики в Україні: нестабільність політичної й операційної сфрер; недосконала нормативно-правова база у сорері стимулювання і підтримки інновацій; неефективне інституційне забезпечення інноваційної діяльності в органах влади; недостатньо еорективна кадрова політика щодо зменшення опору персоналу інноваціям в органах влади; недостатній рівень мотивації персоналу органів влади щодо здобуття та застосування ним нових компетентностей у сорері інновацій тощо. Отже, у контексті вищевикладеного виникає потреба у використанні комплексного методичного підходу до забезпечення дієвої інноваційної діяльності в органах влади, що дасть змогу підвищити результативність системи публічного управління у цілому та, як наслідок, підвищити ефрективність реалізації державної економічної політики. Окрім того, для підвищення якості та дієвості інноваційна діяльність в органах влади потребує належного забезпечення: нормативно-правового, інституційного, кадрового, мотиваційного, науково-методичного, фрінансового, інфрормаційно-комунікаційного:

1) гармонізація нормативно-правового забезпечення в країні на основі забезпечення ефективної реалізації механізмів публічно-приватного партнерства, розвитку науково-інноваційного співробітництва державного та недержавного секторів науки, закладів вищої освіти, наукових установ із реальним сектором економіки;

2) удосконалення інституційного забезпечення інноваційної діяльності в органах публічної влади на основі створення віртуальних результативних підрозділів в їх організаційних структурах управління, зокрема офрісів інноваційної діяльності (доповнено на основі [9]). Значущість створення таких підрозділів в органах влади, підпорядкованих загальним цілям реформ в Україні, пов'язана 3 відсутністю спеціальних структур, відповідальних за інноваційний розвиток країни, як на державному, так і на регіональному та місцевому рівнях. Окрім того, організаційна структура влади, яка регулює питання інноваційної діяльності в Україні, характеризується відсутністю чіткого зв'язку як між рівнями влади, так і між функціональними підрозділами. У розвинених країнах світу, навпаки, намітилася тенденція створення і розвитку інноваційної інсрраструктури, що всебічно підтримує інновації в органах влади на всіх рівнях управління. Сутність і призначення офрісу інноваційної діяльності, головну мету, основні і допоміжні завдання, а також його організаційні форми визначено у попередньому науковому дослідженні автора (доповнено на основі [9]). Необхідність створення офрісу інноваційної діяльності в органах влади виникає за умов, коли кількість інновацій та їх масштаб починають створювати проблеми з керованістю, зникає прозорість, виникає різнорідна звітність, що не дає змоги проаналізувати стан реалізації всіх інновацій. Отже, створення офрісу інноваційної діяльності в органах влади в Україні дасть змогу не лише здійснювати координацію і підтримку їхньої інноваційної діяльності для створення сприятливого інноваційного середовища, а й раціонально використовувати соціально-економічний потенціал країни для реалізації державної і регіональної економічної політики;

3) реалізація повноцінної інноваційної кадрової політики в органах влади, яка буде спрямована не лише на посилення профресійної спрямованості та активізацію праці потенційних упроваджувачів нововведень, а й на створення мотиваційного середовища для активізації впровадження інновацій, від чого напряму залежить ефективність державної і регіональної економічної політики, а також конкурентоспроможність регіону і країни у цілому. Слід підкреслити, що впровадження будь-якої інновації у сорері публічного управління вимагає відповідних професійних компетентностей персоналу, який є ключовим стратегічним ресурсом для якісного виконання управлінських функцій та досягнення цілей публічного управління. Причому розвиток та створення можливостей для розкриття креативного потенціалу публічних службовців стає головним системним завданням управлінських інновацій. Поряд із цим в органах влади в умовах рефрорм значною мірою зростає роль команд у забезпеченні ефективної інноваційної діяльності, отже, сучасні публічні службовці повинні працювати як ефективна команда. Для здійснення дієвої інноваційної діяльності в органах влади слід створити еорективну команду публічних службовців. І3 цією метою важливо виявити: психологічні особливості діяльності публічних службовців в органах влади; рівень їхньої психологічної готовності до роботи в команді у процесі здійснення інноваційної діяльності (профресійно-організаційні характеристики - посада в організації, освіта, стаж професійної діяльності та соціально-демографрічні характеристики - стать, вік); психологічні чинники, які впливають на них; психологічні умови підготовки службовців до роботи в команді (усвідомлення ролі та психологічних особливостей діяльності команд під час створення і запровадження інновацій; здобуття професійних компетентностей, необхідних для роботи в команді; усвідомлення впливу власних індивідуально-психологічних характеристик на рівень психологічної підготовки до роботи в команді в органах влади та опанування можливих способів їх розвитку). Із метою відбору службовців для створення результативної команди під час здійснення інноваційної діяльності доцільно проводити їх психодіагностику із застосуванням тесту 
М. Белбіна, що дасть змогу не лише оцінити інтелектуальні, професійні та особистісні якості службовців, а й підібрати психологічно сумісних упроваджувачів інновацій відповідно до необхідних (еорективних) командних ролей;

4) підвищення мотивації впроваджувачів інновацій в органах влади, що дасть змогу досягти значного соціального й економічного ефектів під час реалізації державної економічної політики в Україні. Слід відзначити особливу необхідність дієвого заохочення творчості й ініціатив щодо нових способів розв'язання соціально-економічних проблем, використання наявного творчого і компетентнісного потенціалу публічних службовців, поліпшення інформаційного середовища та фрормування нової управлінської культури. Окрім сорери мотивації творчої діяльності публічних службовців органів влади, інноваційні зміни повинні також торкатися орієнтирів і показників виконання обов'язків публічними службовцями та керівниками, питань корпоративної культури 3 формуванням нової етики публічної служби;

5) посилення науково-методичного забезпечення інноваційної діяльності в органах публічної влади на основі запровадження інноваційної культури в органах влади для досягнення відкритості і готовності кадрів до нововведень. Слід зауважити, що не менш важливими (сприятливими) передумовами (ресурсами) для успішного здійснення інноваційної діяльності є види та способи супроводу, що забезпечують фрормування інноваційної культури. Ступінь розвиненості загальної та інноваційної культури, національний менталітет, соціально-економічний статус, освіта, світогляд норми та цінності, переконання, відкритість до змін та спілкування тощо є тими чинниками, що визначають інноваційну активність потенційних упроваджувачів. У європейському просторі саме рівень цього чинника $є$ найменшим для українського суспільства. Результати досліджень показують, що відсутність професійної компетентності (публічноуправлінських знань, відмінності рівнів та профрілів базової освіти кадрового складу публічної служби України) є надто впливовими чинниками спротиву нововведенню. Рівень інноваційної культури у цьому середовищі можна підвищити шляхом масштабного здійснення інноваційно орієнтованого професійного навчання у рамках реалізації державно-управлінських реформ, зокрема під час підвищення кваліфікації кадрів та підготовки магістрів публічного управління та адміністрування. Це, як наслідок, забезпечить підвищення інноваційної спрямованості органів влади та дасть змогу, з одного боку, підвищити ефективність реалізації економічної політики держави, a, 3 іншого досягти високого суспільного розвитку в країні;

6) удосконалення інформаційно-комунікаційного забезпечення інноваційної діяльності в органах влади на основі масштабного запровадження сучасних інфрормаційно-комунікаційних технологій, що прискорить перехід до повноцінного «електронного уряду» і підвищить рівень професійної мобільності службовців під час інноваційної діяльності. Отже, особливу увагу слід приділити ефрективному використанню механізму електронного урядування в органах влади та сучасних інфрормаційно-комунікаційних технологій під час здійснення їхньої інноваційної діяльності;

7) удосконалення фрінансового забезпечення інноваційної діяльності в органах влади на основі активного запровадження методології проєктного підходу до підвищення фрінансової спроможності органів влади (розроблення і реалізація проєктів регіонального розвитку, грантрайтінг тощо). В умовах дотаційності місцевих бюджетів в Україні органам влади є доцільним розробляти і реалізовувати проєкти, використовуючи підтримку міжнародних організацій та фрондів (міжнародна науково-технічна допомога). Слід також зауважити, що під час реалізації інноваційних проєктів органами влади важливо активізувати їх взаємодію 3 єврорегіонами, які також сприяють здійсненню проєктної діяльності в Україні (найбільш значущими з них є єврорегіони «Дністер» і «Карпати»). Отже, активізація органів публічної влади щодо розроблення та реалізації різних проєктів дасть їм змогу не лише розв'язати нагальні проблеми на території України на основі залучення донорських коштів різних міжнародних організацій і фондів, а й підвищити свою фрінансову спроможність. Це, своєю чергою, допоможе зменшити фрінансове навантаження на державний бюджет (зменшення суми дотацій місцевим бюджетам і бюджетам об'єднаних територіальних громад із боку держави) і сприятиме більшій державній підтримці реального сектору економіки (доповнено на основі [15]).

Ґрунтуючись на вищезазначеному та беручи до уваги відповідні наукові розробки [8; 9; 15], удосконалено методичний підхід до забезпечення дієвої інноваційної діяльності в органах влади в Україні, що дасть змогу підвищити ефективність реалізації державної та регіональної економічної політики в умовах реформ (рис. 1). На цьому ж рис. 1 відображено зв'язок між процесом забезпечення дієвої інноваційної діяльності в органах влади та процесом реалізації ефективної державної й регіональної економічної політики, який ґрунтується на здійсненні результативного публічного управління та адміністрування (дієва інноваційна діяльність у системі публічного управління й адміністрування забезпечить реалізацію якісної державної і регіональної політики та досягнення високого соціально-економічного розвитку в країні).

Запропонований методичний підхід на відміну від існуючого акцентує увагу на вдосконаленні нормативно-правового, інституційного, 


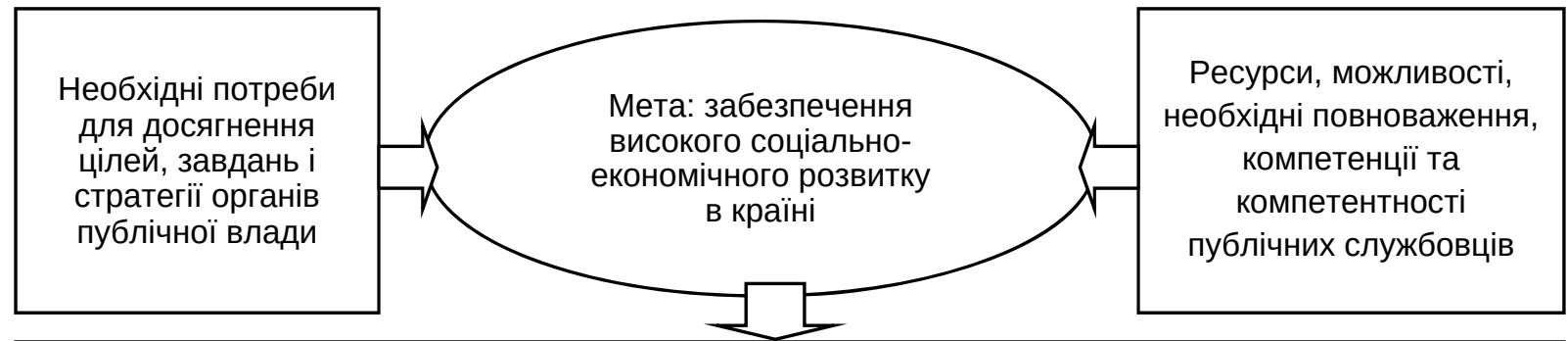

Обґрунтування необхідності здійснення інноваційної діяльності органами публічної влади на основі співставлення: нагальних потреб для досягнення цілей, завдань і стратегії органів влади та ресурсів, можливостей, повноважень, компетенцій і професійних компетентностей службовців
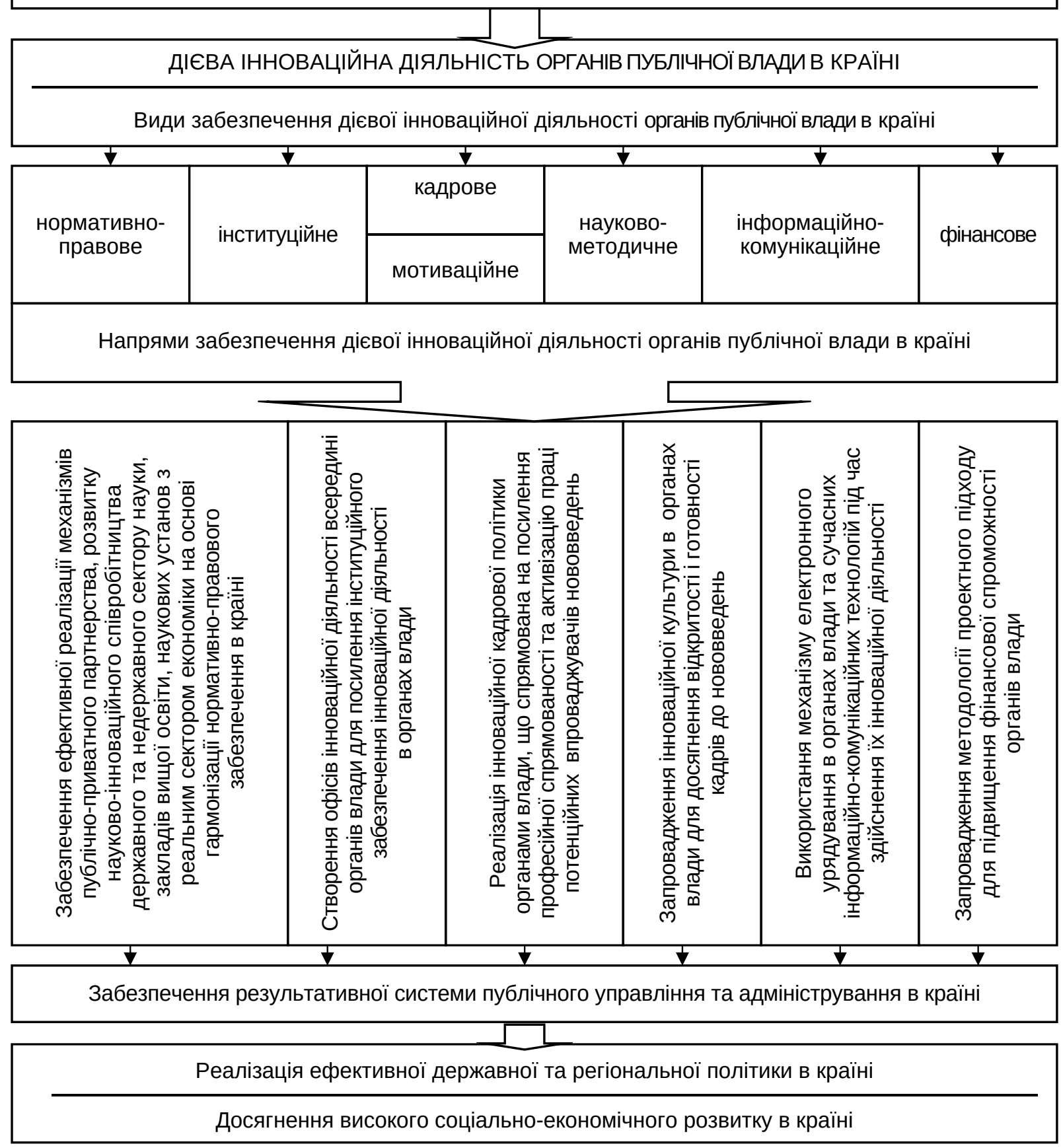

Рис. 1. Методичний підхід до забезпечення дієвої інноваційної діяльності в органах влади в Україні (доповнено на основі [15]) 
кадрового, мотиваційного, науково-методичного, інорормаційно-комунікаційного та фрінансового забезпечення інноваційної діяльності в органах влади, що дасть змогу підвищити ефективність реалізації економічної політики держави та, як наслідок, досягти високого суспільного розвитку в країні. При цьому окреме місце у зазначеному методичному підході виділено процесу реалізації інноваційної кадрової політики, яка базується: на управлінні профресійною компетентністю публічних службовців (використання шкали оцінювання рівня компетентності публічних службовців та коригування цього рівня), на оцінюванні стану готовності публічних службовців до нововведень (вибір певних критеріїв оцінювання) та на управлінні опором інноваціям в органах влади. Основна мета реалізації зазначеної інноваційної кадрової політики - сорормувати здатність (набір профресійних компетентностей) публічних службовців діяти в сучасних умовах суспільного розвитку та бути відкритими до впровадження відповідних новацій.

Отже, використання запропонованого методичного підходу до забезпечення дієвої інноваційної діяльності в органах влади дасть змогу створити сприятливе інноваційне середовище всередині органів влади, які відповідальні за виконання важливих соціальних, економічних та інших фрункцій в Україні, і, як наслідок, більш раціонально використовувати наявні внутрішні і зовнішні ресурси для реалізації економічної політики в Україні.

Висновки 3 проведеного дослідження. У роботі доведено, що важливою передумовою стабільної роботи системи публічного управління та адміністрування в умовах ресрорм $є$ обґрунтування умов забезпечення результативного фрункціонування органів публічної влади в країні, яке може бути досягнуто за рахунок здійснення дієвої інноваційної діяльності. Отже, саме інноваційна діяльність визначає подальший розвиток органів влади, відповідальних за виконання важливих функцій (соціальних, економічних тощо) в Україні. У дослідженні розкрито значення підвищення дієвості здійснення інноваційної діяльності в органах влади для реалізації ефрективної економічної політики держави та досягнення високого соціальноекономічного розвитку в Україні.

На основі проведеної порівняльної статистики щодо рейтингу України в інноваційній сорері серед інших країн світу протягом останніх років виявлено, що Україна має потенціал до інноваційного розвитку, однак поки що є значні перешкоди для того, щоб наша країна посідала перші місця у міжнародних індексах у сфері інновацій. У дослідженні визначено основні перешкоди проведення ефрективної інноваційної політики в Україні: нестабільність політичної й операційної сорер; недосконала нормативно-правова база у сорері стимулювання і підтримки інновацій; неефективне інституційне забезпечення інноваційної діяльності в органах влади; недостатньо ефективна кадрова політика щодо зменшення опору персоналу інноваціям в органах влади; недостатній рівень мотивації персоналу органів влади щодо здобуття та застосування ним нових компетентностей у сорері інновацій тощо. У зв'язку із цим у роботі запропоновано методичний підхід до забезпечення дієвої інноваційної діяльності в органах влади. Цей методичний підхід на відміну від існуючого акцентує увагу на вдосконаленні нормативно-правового, інституційного, кадрового, мотиваційного, науковометодичного, інфрормаційно-комунікаційного та фрінансового забезпечення інноваційної діяльності в органах влади. Окреме місце у зазначеному методичному підході відведено процесу реалізації інноваційної кадрової політики, яка базується на управлінні професійною компетентністю публічних службовців, на оцінюванні стану готовності публічних службовців до нововведень та на управлінні опором інноваціям в органах влади. Використання запропонованого методичного підходу до забезпечення дієвої інноваційної діяльності в органах влади дасть змогу підвищити ефективність реалізації економічної політики держави та, як наслідок, досягти високого суспільного розвитку в країні. Автором також визначено зв'язок між процесом забезпечення дієвої інноваційної діяльності в органах влади та процесом реалізації ефективної державної й регіональної економічної політики, який ґрунтується на здійсненні результативного публічного управління та адміністрування (дієва інноваційна діяльність у системі публічного управління й адміністрування забезпечить реалізацію якісної державної і регіональної політики та досягнення високого соціально-економічного розвитку в країні).

\section{БІБЛІОГРАФІЧНИЙ СПИСОК:}

1. Дегтярьова І.О. Зарубіжний досвід інституційної підтримки інновацій державного і муніципального управління. Інституційне забезпечення кадрової політики у державному управлінні: становлення та розвиток : матеріали Всеукр. наук.-практ. конор. за міжнар. участю, м. Київ, 29 травня 2015 р. Київ : НАДУ, 2015. С. 8-10.

2. Карпова Ю.А. Инновации, интеллект, образование : монограсрия. Москва : МГАУ, 1998. 305 с.

3. Никифоров А.Є. Інноваційна діяльність: теорія і практика державного управління : монографія. Київ : KHEУ, 2010. 420 c.

4. Петришина М.О. Загальні засади запровадження інноваційної моделі розвитку української держави: муніципальний аспект. Право та інновації. 2013. № 4. C. 15-26. URL: http://ndipzir.org.ua/wp-content/uploads/2014/01/Petryshyna.pdf (дата звернення: 28.04.2021).

5. Пригожин А.И. Нововведения: стимулы и препятствия : монография. Москва : Политиздат, 1989. $271 \mathrm{c}$. 
6. Роджерс Е.М. Дисуузія інновацій / пер. 3 англ. В. Старка. Київ : Києво-Могилянська академія, 2009. $591 \mathrm{c.}$

7. Управління стратегічним розвитком об'єднаних територіальних громад: інноваційні підходи та інструменти : монограсрія / С.М. Серьогін та ін. ; за заг. та наук. ред. С.М. Серьогіна, Ю.П. Шарова. Дніпро : ДРІДУ НАДУ, 2016. 276 с.

8. Публічне управління та адміністрування у забезпеченні регіонального розвитку : монограсрія / Н.Л. Гавкалова та ін. ; за заг. ред. докт. екон. наук, професора Н.Л. Гавкалової. Харків : ХНЕУ ім. С. Кузнеця, 2019. 390 с.

9. Шумська Г.М. Концептуальні засади здійснення інноваційної діяльності органами публічної влади як основи соціально-економічного розвитку України. Економіка та суспільство. 2018. Вип. 18. С. 432-442.

10. Global Innovation Index (2020). URL: https://www.wipo.int/ global_innovation_index/en/2020/ (дата звернення: 26.04.2021).

11. Інноваційний індекс Bloomberg 2020. URL: https://www.theceomagazine.com/business/innovationtechnology/most-innovative-countries-2020/ (дата звернення: 26.04.2021).

12. Про схвалення Стратегії розвитку сфрери інноваційної діяльності на період до 2030 року : Розпорядження Кабінету Міністрів України від 10 липня 2019 р. № 526-р / Кабінет Міністрів України. URL: https://zakon.rada.gov.ua/ laws/show/526-2019 (дата звернення: 20.04.2021).

13. Офіційний сайт Державної служби статистики України. URL: http://www.ukrstat.gov.ua/ (дата звернення: 22.04.2021).

14. Звіт щодо розвитку електронного урядування у 2020 році. URL: https://publicadministration.un.org/ egovkb/en-us/Reports/UN-E-Government-Survey-2020 (дата звернення: 22.04.2021).

15. Шумська Г.М. Теоретичні аспекти забезпечення дієвої інноваційної діяльності органами публічної влади як основи розвитку національної економіки. Інфраструктура ринку. 2020. Вип. 43. С. 94-101.

\section{REFERENCES:}

1. Dehtiarova I.O. (2015) Zarubizhnyi dosvid instytutsiinoi pidtrymky innovatsii derzhavnoho i munitsypalnoho upravlinnia [Foreign experience of institutional support of innovations of state and municipal administration]. Instytutsiine zabezpechennia kadrovoi polityky u derzhavnomu upravlinni: stanovlennia ta rozvytok: materialy Vseukr. nauk.-prakt. konf. za mizhnar. uchastiu (Ukraine, Kyiv, 29 May, 2015). Kyiv: NADU, pp. 8-10.

2. Karpova Yu.A. (1998) Innovatsii, intellekt, obrazovanie [Innovations, intellect, education]. Moscow: MGAU. (in Russian)

3. Nykyforov A.Ye. (2010) Innovatsiina diialnist: teoriia i praktyka derzhavnoho upravlinnia [Innovative activity: theory and practice of state administration]. Kyiv: KNEU. (in Ukrainian)

4. Petryshyna M.O. (2013) Zahalni zasady zaprovadzhennia innovatsiinoi modeli rozvytku ukrainskoi derzhavy: munitsypalnyi aspect [General principles of input of innovative model of development of the
Ukrainian state: municipal aspect]. Law and innovations, no. 4, pp. 15-26. Available at: http://ndipzir.org.ua/wpcontent/uploads/2014/01/Petryshyna.pdf (accessed 28 April 2021).

5. Prigozhin A.I. (1989) Novovvedeniya: stimuly i prepyatstviya [Innovations: stimuli and obstacles]: monografiya. Moscow: Politizdat. (in Russian)

6. Rodzhers E.M. (2009) Dyfuziia innovatsii [Diffusion of innovations]. Kyiv: Kyievo-Mohylianska akademiia. (in Ukrainian)

7. S. M. Serjoghin, Ju.P. Sharov, Je.I. Borodin, N.T. Ghoncharuk (2016) Upravlinnja strateghichnym rozvytkom ob'jednanykh terytorialjnykh ghromad: innovacijni pidkhody ta instrumenty [Managing Strategic Development of United Territorial Communities: Innovative Approaches and Tools]. Dnipro: DRIDU NADU. (in Ukrainian)

8. Publichne upravlinnja ta administruvannja $u$ zabezpechenni reghionaljnogho rozvytku: monoghrafija [Public administration in regional development] / N.L. Gavkalova, G.M. Shumska, V.I. Melnyk ta in.; za zagh. red. dokt. ekon. nauk, profesora N.L. Gavkalovoji. Kharkiv: KhNEU im. S. Kuznecja, 2019.

9. Shumska G.M. (2018) Konceptualjni zasady zdijsnennja innovacijnoji dijaljnosti orghanamy publichnoji vlady jak osnovy socialjno-ekonomichnogho rozvytku Ukrajiny [Conceptual principles of innovation activity of public authorities as a basis of socio-economic development of Ukraine]. Ekonomika ta suspiljstvo. Vypusk 18, pp. 432-442. Mukachevo: Mukachivsjkyj derzhavnyj universytet.

10. Global Innovation Index (2020). Available at: https://www.wipo.int/global_innovation_index/en/2020/ (accessed 26 April 2021)

11. Innovacijnyj indeks Bloomberg [Innovation Index] (2020). Available at: https://www.theceomagazine.com/ business/innovation-technology/most-innovative-countries-2020/ (accessed 26 April 2021).

12. Pro skhvalennja Strateghiji rozvytku sfery innovacijnoji dijaljnosti na period do 2030 roku [On approval of the Strategy for development of the sphere of innovative activity for the period till 2030]: Rozporjadzhennja Kabinetu Ministriv Ukrajiny vid 10 Iypnja 2019 r. № 526-r / Kabinet Ministriv Ukrajiny. Available at: https://zakon.rada.gov.ua/laws/show/526-2019 (accessed 10 April 2020).

13. Ofitsiinyi sait Derzhavnoi sluzhby statystyky Ukrainy [Official site of the State Statistics Service of Ukraine]. Available at: http://www.ukrstat.gov.ua/ (accessed 22 April 2021).

14. Zvit shchodo rozvytku elektronnoho uriaduvannia $u 2020$ rotsi [Report on the development of e-government in 2020]. Available at: https://publicadministration. un.org/egovkb/en-us/Reports/UN-E-Government-Survey-2020 (accessed 22 April 2021).

15. Shumska G.M. (2020) Teoretychni aspekty zabezpechennia diievoi innovatsiinoi diialnosti orhanamy publichnoi vlady yak osnovy rozvytku natsionalnoi ekonomiky [Theoretical aspects of ensuring effective innovative activity by public authorities as a basis for national economy development]. Infrastruktura rynku. Vypusk 43, pp. 94-101. Odesa: Prychornomorskyi naukovo-doslidnyi instytut ekonomiky ta innovatsii. 